\title{
A new earthworm species within a controversial genus: Eiseniona gerardoi sp. n. (Annelida, Lumbricidae) - description based on morphological and molecular data
}

\author{
Darío J. Díaz Cosín ${ }^{1, \dagger}$, Marta Novo ${ }^{1,2, \neq}$, Rosa Fernández ${ }^{1,3, \$}$, \\ Daniel Fernández Marchán ${ }^{1,1}$, Mónica Gutiérrez',
}

I Departamento de Zoología y Antropología Fisica, Facultad de Biología, Universidad Complutense de Madrid, C/ José Antonio Nováis 2, 28040, Madrid, Spain 2 Cardiff School of Biosciences, Cardiff University, BIOSI 1, Museum Avenue, Cardiff CF10, 3TL, UK3 Museum of Comparative Zoology, Department of Organismic and Evolutionary Biology, Harvard University, 26 Oxford Street, Cambridge, MA 02138, USA

† http://zoobank.org/38538B17-F127-4438-9DE2-F9D6C597D044

‡ http://zoobank.org/79DA5419-91D5-4EAB-BC72-1E46F10C716A

§ http://zoobank.org/99618966-BB50-4A01-8FA0-7B1CC31686B6

| http://zoobank.org/CAB83B57-ABD1-40D9-B16A-654281D71D58

I http://zoobank.org/E1A7E77A-9CD5-4D67-88A3-C7F65AD6A5BE

Corresponding author: Dario J. Díaz Cosín (dadico@bio.ucm.es)

Academic editor: R. Blakemore | Received 17 February 2014 | Accepted 25 March 2014 | Published 9 April 2014

http://zoobank.org/F5AC3116-E79E-4442-9B26-2765A5243D5E

Citation: Cosín DJD, Novo M, Fernández R, Marchán DF, Gutiérrez M (2014) A new earthworm species within a controversial genus: Eiseniona gerardoi sp. n. (Annelida, Lumbricidae) - description based on morphological and molecular data. ZooKeys 399: 71-87. doi: 10.3897/zookeys.399.7273

\begin{abstract}
The morphological and anatomical simplicity of soil dwelling animals, such as earthworms, has limited the establishment of a robust taxonomy making it sometimes subjective to authors' criteria. Within this context, integrative approaches including molecular information are becoming more popular to solve the phylogenetic positioning of conflictive taxa. Here we present the description of a new lumbricid species from the region of Extremadura (Spain), Eiseniona gerardoi sp. n. The assignment to this genus is based on both a morphological and a phylogenetic study. The validity of the genus Eiseniona, one of the most controversial within Lumbricidae, is discussed. A synopsis of the differences between the type species and the west-European members of the genus is provided.
\end{abstract}

Copyright D.J. Díaz Cosin et al. This is an open access article distributed under the terms of the Creative Commons Attribution License (CC BY 4.0), which permits unrestricted use, distribution, and reproduction in any medium, provided the original author and source are credited. 


\section{Keywords}

Earthworms, lumbricids, Eiseniona, species description

\section{Introduction}

Earthworm fauna is still poorly known within vast areas of the Iberian Peninsula. The available data indicate the common presence of cosmopolitan species such as Aporrectodea trapezoides (Dugès, 1828) or $A$. rosea (Savigny, 1826). In contrast, other species show more restricted distributions but are locally abundant (Díaz Cosín et al. 1992, Rodríguez et al. 1997). The region of Extremadura is one of the best documented, thanks to the work by Sánchez et al. $(1998,1999)$. These authors found that $A$. trapezoides and $A$. rosea are the dominant species, while other species can be locally important in river sides and flooded areas, such as the species of the complex Allolobophora molleri Rosa, 1889 sensu Barros et al. (1992) that was placed in Eophila by Blakemore (2008).

An intensive earthworm sampling campaign was accomplished between 2009 and 2012 in the surroundings of Plasencia (North of Cáceres, Extremadura, Spain) within the European Project "BioBio, Biodiversity Indicators for European Farming Systems, Indicators for Biodiversity in Organic and Low Input Farming Systems". The Spanish team within this project studied the potential use of soil fauna as bioindicators in dehesas (i.e., Mediterranean grazed open woodlands of Quercus ilex Linné and olive groves under different types of land management. Among the several thousands of earthworm specimens collected during this sampling campaign, nineteen individuals sampled close to El Bronco (Cáceres, Spain) are of special taxonomical interest as they represent a new species as described in the present study.

The taxonomical assignment to a genus level in earthworm lumbricid taxonomy is confusing and varies regarding the criteria used by the different authors. In addition, it lacks robustness because it is not necessarily based on phylogenetic relationships. The number of genera proposed for the family Lumbricidae varies from five when reviewed by Michaelsen (1900) (Eiseniella, Eisenia, Helodrilus -with four subgenera - Octolasium and Lumbricus) to 44 proposed by Blakemore (2008) or 45 considered by Qiu and Bouché (1998a), including 29 subgenera. Some of these genera are well-defined and characterized by consistent and stable characters. A good example is the genus Lumbricus, with a tanylobic prostomium, paired chaetae and reddish body colour. Unfortunately, this is not the case in the great majority of the other genera, as often overlapping or slightly variable characters are used to define them. Therefore, the proper assignment to the level of genus is challenging and sometimes even subjective, but should nevertheless comply with ICZN requirements to be consistent with its type-species.

Soil dwelling animals are subject to a series of limitations in their corporal design. This is reflected in earthworms that present a very simple body externally without many differential morphological characters. The position of clitellum and tubercula pubertatis, type of prostomium, pigmentation, chaetal arrangement, number and position of spermathecae, seminal vesicles, Morren's glands, nephridia or typhosole are 
some of the most widely-used morphological characters in earthworm systematics. Nevertheless, these characters may probably have evolved as adaptations to a particular soil environment or independently in several phylogenetic lineages, therefore hindering establishment of a robust taxonomical system based on morphology. The solution to this taxonomical chaos would be the phylogenetic resolution of earthworms based on molecular and morphological studies. This would allow the generation of stable and robust phylogenies in which systematic classifications are properly defined. Unlike earthworms from the family Hormogastridae (e.g., Novo et al. 2011), only some attempts have been done to study the phylogenetic relationships of lumbricids (e.g., Briones et al. 2009). Nonetheless, these studies are limited because of incomplete sampling or limited number of genes sequenced. Fortunately, a multigene phylogeny of lumbricid earthworms represented by a high number of species and genera is about to be published (Pérez Losada et al., pers. comm.) and hopefully it will help to convert lumbricid systematics into a more stable system.

In the context of this controversial classification of genera in lumbricid earthworms, one of the most conflictive ones is Eiseniona (Omodeo, 1956). This genus was established by Omodeo (1956) and was accepted by some authors (Álvarez 1970; Qiu and Bouché 1998a, d; Omodeo and Rota 2004; Rota 2013) but rejected by others (Bouché 1972; Zicsi 1982; Easton 1983; Mrsic 1991 and Blakemore 2008). Most of the species included in Eiseniona are distributed in Italy, Greece and other countries of Central or Eastern Europe. Some examples of species described in Western Europe are E. paradoxa (Cognetti, 1904) and E. gavarnica (Cognetti, 1904) in France [both retained in genus Orodrilus Bouche, 1972 by Blakemore (2008)] and in the Iberian Peninsula Eiseniona oliveirae (Rosa, 1894), Eiseniona carpetana (Álvarez, 1970) and Eiseniona albolineata Díaz Cosín et al., 1989 [the former retained in Allolobophora Eisen, 1874 and the latter two retained in genus Iberoscolex Qiu \& Bouche, 1998 by Blakemore (2008)].

Despite the extended use of morphological and anatomical characters in earthworm taxonomy, during the last years the concept of integrative taxonomy as a tool to describe and delimit species has become more popular. This concept, consisting of a multidisciplinary approach including the morphological, molecular, ecological and geographical available data, has been applied to earthworms (e.g., Novo et al. 2012 for hormogastrids, Blakemore and Kupriyanova 2010, Blakemore 2010, Blakemore et al. 2010, Blakemore and Grygier 2011 and Blakemore 2012a for lumbricids) The implementation of molecular techniques has allowed presumption of a high cryptic diversity in earthworms completely unknown when based on traditional systematic methods (e.g. King et al. 2008, Novo et al. 2009, 2010, Dupont et al. 2011, Fernández et al. 2011), but see critique in Blakemore et al. (2010). In addition, molecular barcoding has become a widely used technique for taxonomical evaluation, allowing interesting discoveries such as the proposed separation of $L$. terrestris and L. herculeus (James et al., 2010), but see correction by Blakemore (2013).

In this context, this manuscript aims to describe a new lumbricid species (E. gerardoi sp. n.) based on morphological, molecular and ecological data. 


\section{Material and methods}

\section{Earthworm specimens and sampling points}

Nineteen individuals were collected at four different but geographically-close sampling points nearby El Bronco (Cáceres, Extremadura, Spain). Soil was a sandy-loam on underlying slate (Figure 1); collectors G. Moreno, E. Juárez.

D4 Le1: 2 ex. (1 adult, 1 subadult) $\left(40^{\circ} 12^{\prime} 42.76^{\prime \prime} \mathrm{N}, 6^{\circ} 19^{\prime} 0.68^{\prime \prime} \mathrm{W}\right)$. Altitude 430 $\mathrm{m}$. Grazed dehesa with Quercus ilex. Mean precipitation $876 \mathrm{~mm}$. Present plant species: Eleocharis palustris, Pulicaria paludosa. Other earthworm species: A. molleri 1 ex. $(0.75 \mathrm{~g})$.

D4 R2: 2 ex. (2 adults) (40²' $\left.12^{\prime} 5.22^{\prime \prime N}, 6^{\circ} 18^{\prime} 39.22^{\prime \prime W}\right)$. Altitude $414 \mathrm{~m}$. Grazed dehesa with Quercus ilex. Mean precipitation $876 \mathrm{~mm}$. Present plant species: Anthoxanthum aristatum, Isoetes hystris. Other earthworm species: A. molleri 8 ex. $(6.72 \mathrm{~g}), A$. trapezoides $16 \mathrm{ex}$. (4.96 g).

D4 S1: 2 ex. (2 subadults) $\left(40^{\circ} 12^{\prime} 41.51^{\prime \prime N}, 6^{\circ} 19^{\prime} 1.20^{\prime \prime W}\right)$. Altitude $430 \mathrm{~m}$. Grazed dehesa with Quercus ilex. Mean precipitation $879 \mathrm{~mm}$. Present plant species: Festuca ampla, Trifolium dubium. Other earthworm species: A. molleri 2 ex. (2.02 g), A. trapezoides 3 ex. (2.01 g).

D5 P2: 13 ex. (5 adults, 8 subadults) $\left(40^{\circ} 13^{\prime} 38.80^{\prime \prime} \mathrm{N}, 6^{\circ} 18^{\prime} 36.04^{\prime \prime W}\right)$. Altitude $428 \mathrm{~m}$. Grazed dehesa with Quercus ilex. Mean precipitation $923 \mathrm{~mm}$. Present plant species: Juncus bufonius, Conyza sp. Other earthworm species: A. molleri 6 ex. (5,32 g), A. rosea 4 ex (1.05 g), A. trapezoides $32 \mathrm{ex}(18,91 \mathrm{~g})$.

\section{Molecular sequencing and analyses}

The following molecular regions were amplified by the methods described in Novo et al. (2011): mitochondrial subunit I of cytochrome c oxidase (COI), 16S rRNA and tRNA Leu, Ala, and Ser (16S-tRNAs), two nuclear ribosomal genes (complete $18 \mathrm{~S}$ and a portion of $28 \mathrm{~S}$ ) and two nuclear protein-encoding genes (histones $\mathrm{H} 3$ and $\mathrm{H} 4$ ).

In order to have an evaluation of the selection of species to include in the molecular analyses, M. Pérez-Losada and J. Domínguez (Universidad de Vigo) kindly compared the sequences of $16 \mathrm{~S}$ and $28 \mathrm{~S}$ rRNA from the specimens included in this study with an unpublished database that includes most lumbricid genera. This comparison provided the first evidence indicating that the new species was closely related to E. albolineata and E. oliveirae. As a second method, we collected some individuals belonging to E. albolineata and sequenced the mitochondrial gene COI. In addition, we retrieved from GenBank all available COI sequences from as many different lumbricid species as possible to date (Table 2), although many of these have their identities unconfirmed. We excluded from the analyses the sequenced 


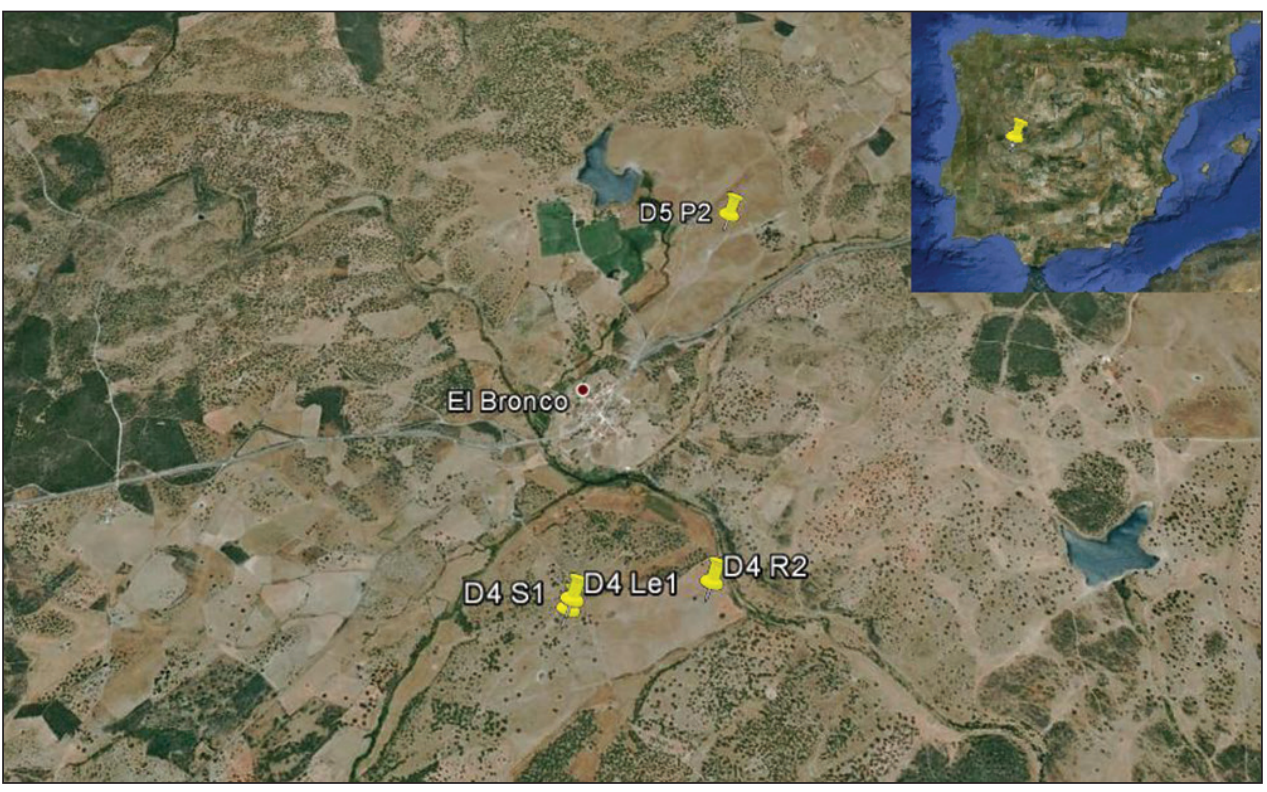

Figure I. Map showing the position of sampling points.

Table I. Paragenetypes (sensu Chakrabarty 2010) of Eiseniona gerardoi sp. n. paratypes, with GenBank accession numbers. As a consequence of the UCM scientific collections restructuring, the earthworms are now deposited within UCMLT (Universidad Complutense de Madrid Lombrices de Tierra).

\begin{tabular}{c|c|c|c|c|c|c}
\hline Voucher & COI & 16S-tRNAs & 18S rRNA & 28S rRNA & H3 & H4 \\
\hline UCMLT 60001 & KF737142 & KF737134 & KF737140 & KF737148 & KF737150 & HG780373 \\
\hline UCMLT 60002 & KF737143 & KF737135 & KF737141 & KF737149 & KF737151 & HG780374 \\
\hline UCMLT 60007 & KF737144 & KF737136 & & & KF737152 & HG780375 \\
\hline UCMLT 60013 & KF737145 & KF737137 & & & & \\
\hline UCMLT 60015 & KF737146 & KF737138 & & & & \\
\hline UCMLT 60017 & KF737147 & KF737139 & & & & \\
\hline
\end{tabular}

genes in the public databases for which information is scarce and biased. Bayesian phylogenetic inference was then explored with the COI sequences as described in Fernández et al. (2012).

Uncorrected pairwise differences were calculated between these species with Arlequin 3.5 (Excoffier et al. 2005).

\section{Data resources}

The data underpinning the analysis reported in this paper are deposited in the Dryad Data Repository at doi: $10.5061 /$ dryad. $5 \mathrm{k} 76 \mathrm{c}$ 
Table 2. Taxa and specimens included in the molecular analysis. GenBank accession numbers are indicated. Species names were literally taken from GenBank. The correct name [after Blakemore (2008)], of the species marked with asterisk is, Bimastos parvus, Allolobophoridella eiseni and Iberoscolex albolineatus.

\begin{tabular}{|c|c|}
\hline Species & COI GeneBank accession number \\
\hline Allolobophora chlorotica & GU013806 \\
\hline Aporrectodea longa & JN850544 \\
\hline Aporrectodea rosea & FJ214232 \\
\hline Aporrectodea trapezoides & JF313567 \\
\hline Aporrectodea tuberculata & JN869877 \\
\hline *Bimastus parvus & EF077605 \\
\hline Dendrobaena attemsi & FJ214224 \\
\hline Dendrobaena octaedra & GU013836 \\
\hline Dendrobaena veneta & FJ214233 \\
\hline Dendrodrilus rubidus & GU013839 \\
\hline Eisenia andrei & DQ914619 \\
\hline${ }^{*}$ Eisenia eiseni & AY874488 \\
\hline Eisenia fetida & EF077596 \\
\hline *Eiseniona albolineata & KF746384 \\
\hline Helodrilus oculatus & FJ374775 \\
\hline Hormogaster elisae & EF653905 \\
\hline Lumbricus festivus & FJ937290 \\
\hline Lumbricus rubellus & GU206189 \\
\hline Lumbricus terrestris & JN869936 \\
\hline Octodrilus juvyi & HE611693 \\
\hline Octolasion cyaneum & JQ909144 \\
\hline Octolasion lacteum & DQ092909 \\
\hline
\end{tabular}

\section{Results}

The specimen with voucher number UCMLT 60000 is the designated holotype. The paratypes bear the numbers UCMLT 60001 to 60018.

\section{Morphological description}

The specimens were sketched using an Olympus binocular microscope with digital camera, dissected, and described.

\section{Taxonomic results}

Phylum Annelida Lamarck, 1802

Subphylum Clitellata Michaelsen, 1919

Class Oligochaeta Grube, 1850

Order Haplotaxida Michaelsen, 1900

Family Lumbricidae Rafinesque-Schmaltz, 1815 


\section{Genus Eiseniona Omodeo, 1956}

Type-species. Allolobophora handlirschi Rosa, 1897 by original designation.

\section{Eiseniona gerardoi Díaz Cosín, sp. n.} http://zoobank.org/E14BF86D-EFF1-47E7-BE5B-6F59ACCDCD4B http://species-id.net/wiki/Eiseniona_gerardoi

Material examined. Holotype. Adult (Catalog \# UCMLT 60000), 40¹3'38.80"N, $6^{\circ} 18^{\prime} 36.04$ "W ("spanish dehesa" mediterranean grazed open woodlands of Quercus ilex), near El Bronco (Cáceres, Spain), leg. G. Moreno, E. Juárez, April 2010.

Paratypes. 18 specimens (Catalog \# UCMLT 60001 to 60018), leg G. Moreno, E. Juárez, April 2010.

Morphological description. External morphology (Figures 2, 3). Length of mature specimens: 21-40 mm, $\overline{\mathrm{x}}$ : 28mm, SD: $5.6 \mathrm{~mm}$, holotype: $31 \mathrm{~mm}$. Diameter: clitellar $\overline{\mathrm{x}}$ : $2.5 \mathrm{~mm}$, SD: $0.4 \mathrm{~mm}$, holotype: $2.5 \mathrm{~mm}$, postclitellar $\bar{x}: 1.8 \mathrm{~mm}$, SD: $0.2 \mathrm{~mm}$, holotype: $1.7 \mathrm{~mm}$. Body cylindrical in the anterior part, wider at clitellum and trapezoidal or rectangular in postclitellar region, with chaetae in the corners. Number of segments: 89 to $124, \bar{x}: 109.5$, SD: 10.7, holotype: 117 . Weight (fixed specimens): 38 to $64 \mathrm{mg}$, $\overline{\mathrm{x}}$ : $52 \mathrm{mg}$, SD: $13 \mathrm{mg}$, holotype $62 \mathrm{mg}$.

Colour: When alive, the anterior part is red-brownish showing noticeable anteroposterior and dorso-ventral gradients. Cream-coloured or whitish clitellum. After a long period within alcohol the red pigment is gradually lost and transformed into brown of different intensities (Figure 2).

Prostomium epilobic $\pm 1 / 3$. No longitudinal lines are noticeable in segments 1 and 2. First dorsal pore in (3/4) 4/5. Nephridial pores inconspicuous in a row slightly above $b$. Spermathecal pores at intersegments $9 / 10$ and $10 / 11$, at the level of chaetae $c d$ (Figure 3).

Male pores as vertical grooves in the segment 15 between chaetae $b$ and $c$ showing small porophores with whitish areolae shape. Female pores in 14 slightly above $b$. Chaetae paired, interchaetal ratio at segment 40, ad: 16, $a b: 1.4, b c: 7, c d: 1, d d: 24$. Chaetae are simple with a wider base and a sharp and bent distal end. (Figure 4).

Clitellum white or cream-coloured, saddle-shaped extending over 22,23-29,30, in the holotype $1 / \mathrm{n} 22,23-29$. When well developed it invades the ventral area and the intersegmental lines are hard to distinguish. Tubercula pubertatis extended as a belt in 23-(27)28,29, in the holotype in 23-29. Occasionally they appear folded or wrinkled. No noticeable papillae are present in any of the specimens.

Internal anatomy. Slightly thickened anterior septa. Last pair of oesophageal hearts in 11. Morren's glands with small diverticula in 10 and little lamellae in 11 and 12 . Crop in 15,16, gizzard in (17) 18,19. First section of the intestine is not dilated. Simple typhlosole pleated, which begins in 20,21 and ends near the anus leaving only 10-15 atyphlosolate segments. 


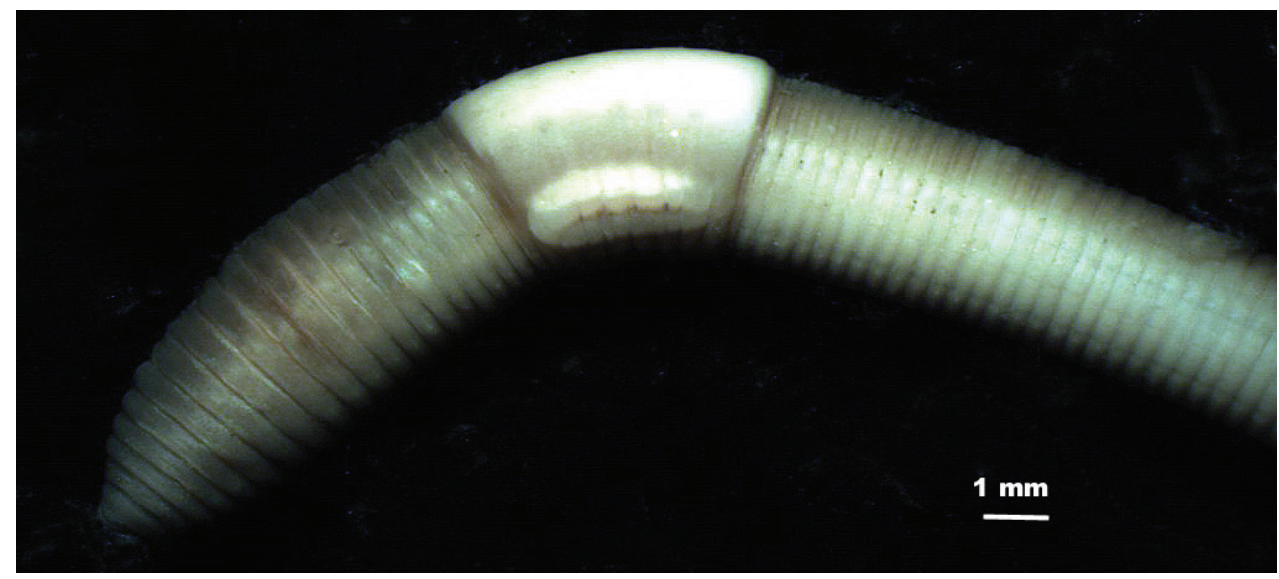

Figure 2. External view of the anterior part of the body of E. gerardoi.

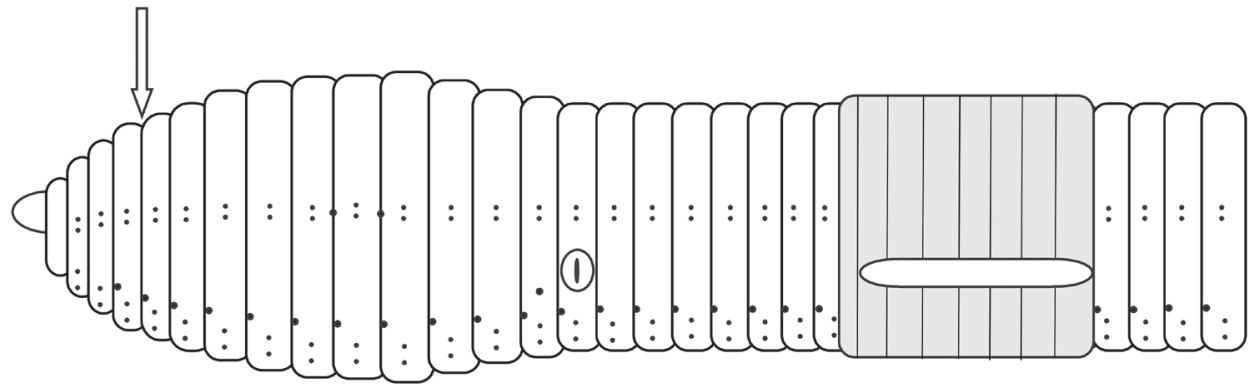

Figure 3. Schematic view of the external morphology of E. gerardoi.

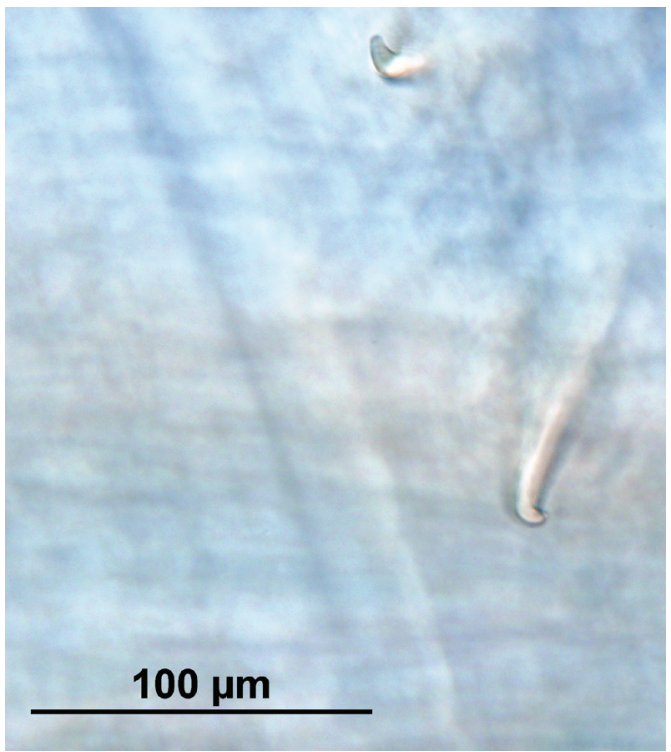

Figure 4. Chaetae $a b$ from segment 40-41 (DIC Nomarski). 


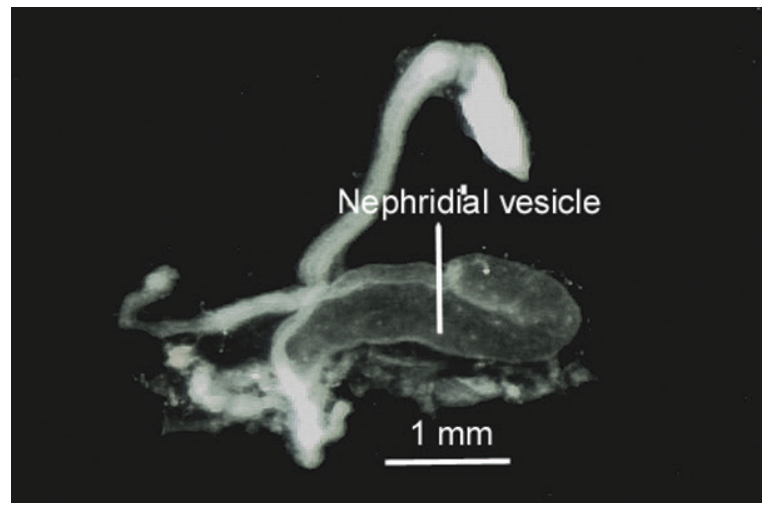

Figure 5. Posterior nephridium isolated by dissection, showing the nephridial curved bladder.

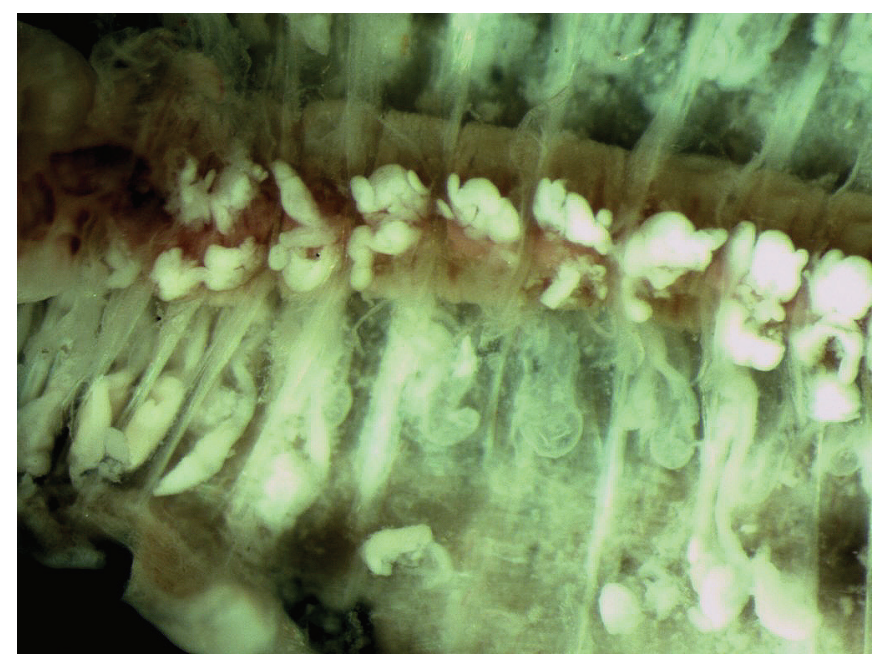

Figure 6. White tissue associated with the dorsal vessel.

Fraying testes and iridescent and very large seminal funnels in 10 and 11 . Three pairs of seminal vesicles in 9,11 and 12 . The last pair is very large pushing back the septum 12/13. Large ovaries and female funnels in 13, ovarian receptacles (ovisacs) in 14. Two pairs of very large and iridescent spermathecae in segments 10 and 11.

In the posterior region of the body the nephridia are much enlarged, the nephridial bladders are curved and J-shaped with curved section $1 / 3$ of total length. (Figure 5).

An important characteristic is the presence of dense white glands on top of the dorsal vessel initially around segment 20 and externally visible as a whitish line extending to the end of the body. (Figure 6).

Distribution. Known only from its type locality.

Etymology. The species is dedicated to Prof. Gerardo Moreno from Centro Universitario de Plasencia, Universidad de Extremadura, Spain. He is the PI for the BioBio program in Spain and collected the specimens described in this paper. 


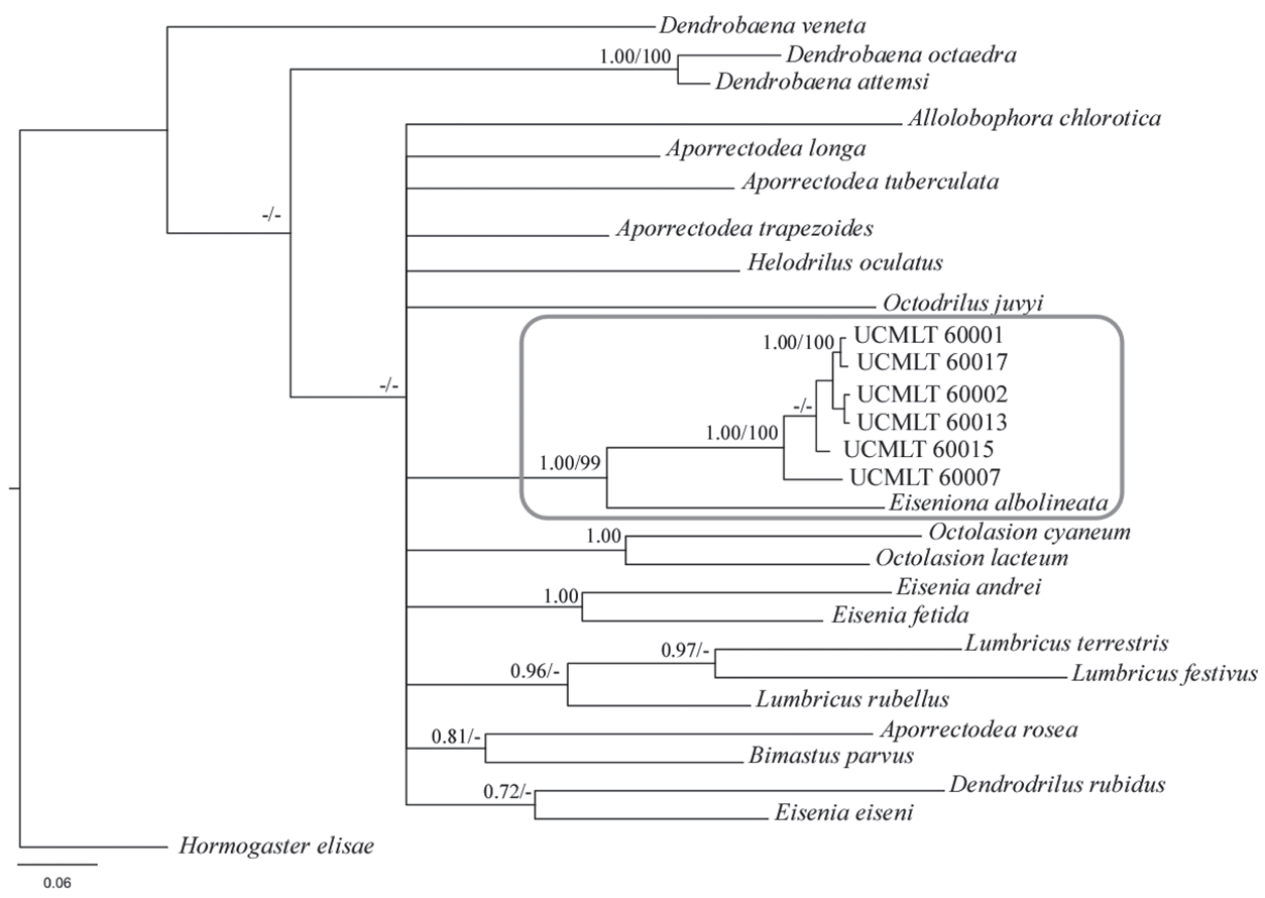

Figure 7. Bayesian inference tree based on COI sequences of $E$. gerardo $i$ and other lumbricids represented in GeneBank. E. gerardoi (see UCMLT codes in Table 1) clusters with E. albolineata.

Molecular characters. Sequences of the used genes have been deposited in GenBank (see Table 1). According to Drs. Pérez Losada and Domínguez (pers. comm.), the $16 S$ and $28 S$ sequences of $E$. gerardoi clustered with the two species classified as Eiseniona, E. albolineata and E. oliveirae.

The phylogenetic tree presented here, based on the COI gene and including some of the available species in GenBank (Figure 7), shows that E. gerardoi specimens form a highly supported group (1.00 posterior probability, 0.99 bootstrap) with E. albolineata. The two species share the presence of whitish glands on top of the dorsal vessel. COI genetic divergence (uncorrected p-distances) between E. albolineata and E. gerardo $i$ is $14.09 \%$, and the intraspecific variability of the latter is $2.81 \%$ showing a very close relationship.

Habitat and ecological characters. All the soils from sampling sites have been developed on slates and are sandy-loams. Precipitation corresponds to the typical values of intermediate semi-humid Spain. The associated species $A$. molleri is always present and this species is bound to terrains that are flooded during several months per year. Additionally, the presence of plants typical from wetlands, such as Eleocharis palustris, Pulicaria paludosa or Juncus bufonius indicates that in these sites there is enough humidity during most of the year, which supports hygrophile communities. Nevertheless they could be desiccated in the summer, which would force the earthworms to 
undergo aestivation in order to survive to these dry periods, resuming activity when humidity is restored. All these details are compatible with the diagnosis of the genus by Omodeo (1956) as he highlighted the semiaquatic characteristics of Eiseniona.

\section{Discussion}

Eiseniona genus was created by Omodeo (1956) for the inclusion of five earthworm species presenting small to medium sizes, number of segments inferior to 170 , closely paired chaetae, Morren's glands with lateral bags in segment 10 and red or light pink subepidermic pigment (absent in some instances). Their clitella start between segments 23 and 27 and tubercula pubertatis appear as continuous bands. Male pores lack the glandular atrium (but show a small atrium in some instances) and papillae are present in segments near the spermathecae and male pores. They show three or four pairs of seminal vesicles, the last reaching to segments 13 or 14 . Their habitat is semiaquatic. Omodeo and Rota (2004) subsequently added or specified other characters such as: "body central and posterior parts with trapezoidal cross section, with the pairs of chaetae at the four corners, nephridial bladders as an inverted J with the ental limb oriented backward, typhlosole cylindrical "en accordéon" spermathecae large, intracoelomic with openings in $9 / 10$ and 10/11, three pairs of seminal vesicles in IX, X, XI the latter being very large, protruding in XIII".

The species originally included in this genus were E. handlirschi (Rosa, 1897) [the designated type, now placed in Aporrectodea according to Blakemore (2008) and Csuzdi (2012)], E. oliveirae (Rosa, 1893), E. intermedia (Michaelsen, 1901), E. paradoxa (Cognetti, 1904) and E. sineporis (Omodeo, 1952). Two new species from Spain were included afterwards, E. carpetana Álvarez, 1970 and E. albolineata Díaz Cosín et al. 1989, Qiu and Bouché (1998a, d) accept the genus Eiseniona in which they include 17 species or subspecies, most of them distributed in the Balkans. However, they place albolineata and carpetana within the genus Iberoscolex; gavarnica and paradoxa within Orodrilus and oliveirae within Koinodrilus Qiu and Bouché (1998b, c). The diagnosis of Eiseniona by these authors is slightly different from the one by Omodeo and Rota (2004), mainly regarding details such as pigment absence, pinnate typhlosole or the presence of four pairs of seminal vesicles in 9, 10, 11 and 12 .

Blakemore (2008) did not accept the genus Eiseniona and considered it as a synonym of Aporrectodea. This author highlighted that it was neither accepted by Bouché (1972), who included hemiandric forms such as paradoxa and gavarnica within the genus Orodrilus and the remainder within Allolobophora. Neither was it accepted by Zicsi (1981, 1982b) nor Mrsic (1991), who note that "the diagnosis of this genus is deficient (the species are hard to distinguish from those of the genus Aporrectodea), so I ignore it." It is evident that the validity of Eiseniona is controversial and in this sense Blakemore (2008) stresses that "These issues need to be thoroughly resolved, with reference to types, before we can consider restoration of either Eiseniona or Koinodrilus". 
Phylogenies recovered by molecular methods can aid to solve this problem by providing key information to support systematics and therefore approaching a natural system (Novo et al. 2011). On this topic Blakemore (2012a) states the need of basing the molecular analyses on the types of the genera. A molecular comparison with the type species $E$. handlirschi could not be carried out in this study due to lack of material. However, in the phylogenetic trees we present here, E. gerardoi clustered together with E. albolineata and it is clearly differentiated from the other genera. The assignment of this new species to the genus Eiseniona is further supported by the fact that analyses with $16 \mathrm{~S}$ and $28 \mathrm{~S}$ regions place it near E. albolineata and E. oliveirae within an unpublished phylogeny of lumbricids that includes most of their genera (Pérez Losada and Domínguez pers. comm.). Hence, the new species can be located within an explicit phylogenetic context, near albolineata and oliveirae regardless of their generic assignment.

Some of the features of our specimens, such as the lack of papillae or the presence of porophores in segment 15, are different from the ones described for most Eiseniona. However male porophores of E. gerardoi are relatively small and Omodeo's (1956) indicates in its diagnosis that in some instances small porophores might be present in the genus. Apart from that, most of the traits of E. gerardoi are compatible with those originally diagnosed as the generic features of Eiseniona. Moreover E. gerardoi shares with $E$. albolineata the white tissue developed on the dorsal vessel.

Considering all this data, we opt to include this new species, at least provisionally, within Eiseniona because it is the less troublesome position within the current genera system for Lumbricidae. This is suggested not only by morphological and ecological considerations but also by the molecular data placing it near E. albolineata and E. oliveirae.

The phylogeny of species historically included within Iberoscolex, Koinodrilus and Eiseniona will need to be thoroughly revised in the future, in order to clarify whether they represent good genera and to find a robust grouping of the species within genera, which does not seem possible exclusively with morphological tools. It is also noteworthy that within Eiseniona there is a group of species from Southern France and Iberian Peninsula and another one from Italy, Greece and Central and Eastern Europe. Future studies will unravel whether these two groups constitute independent phylogenetic units susceptible to be taxonomically divided.

A considerable effort is still necessary to establish a robust genera system based on phylogeny within lumbricids. This system should integrate the study of mitochondrial and nuclear markers with morphological characters and include representatives from all the proposed genera and type species. Until the moment when such big picture is available controversy on lumbricids' genera system will continue and different authors will apply subjective criteria.

\section{Differences with other species of the genus}

The most similar species to $E$. gerardoi regarding clitellum position and tubercula pubertatis is $E$. intermedia, but the last has a much greater size, its tubercula pubertatis start in 
Table 3. Comparison of species living in the western part of the geographic range of Eiseniona. The type species E. handlirschi is included and the hemiandric E. paradoxa and E. gavarnica are excluded.

\begin{tabular}{|c|c|c|c|c|c|}
\hline & E. albolineata & E. carpetana & E. oliveirae & E. gerardoi & E. handlirschi \\
\hline Length (mm) & $78-122$ matures & $52-74$ & $\begin{array}{c}85-110^{*} \\
30-86^{* *} \\
45^{* * *}\end{array}$ & $21-40$ & $\begin{array}{c}50-60^{*} \\
50-170^{* *} \\
50-95^{* * *}\end{array}$ \\
\hline Segments & $138-172$ & $129-150$ & $\begin{array}{c}167^{*} \\
(77) 100-131^{* *} \\
125^{* * *}\end{array}$ & $89-124$ & $\begin{array}{l}120-130^{*} \\
115-163^{* *} \\
78-119^{* * *}\end{array}$ \\
\hline Colour & $\begin{array}{l}\text { Grey, posterior white } \\
\text { line }\end{array}$ & Rose violet & $\begin{array}{l}\text { Light flesh tone* } \\
\text { Brown or violet "in } \\
\text { vivo", greyish when } \\
\text { fixed" } \\
\text { Brown, red*** } \\
\end{array}$ & $\begin{array}{l}\text { Red-brownish “in } \\
\text { vivo", posterior } \\
\text { white line }\end{array}$ & $\begin{array}{c}\text { Colourless* } \\
\text { Colourless** } \\
\text { Pale reddish*** }\end{array}$ \\
\hline Chetae & $\begin{array}{c}\text { Separate } \\
2.5-1.2-2.2-1-5\end{array}$ & Separate & \begin{tabular}{|c|} 
Closely paired* \\
$6.7-1.3-6.2-1-$ \\
$11.8^{* *}$ \\
Closely paired $9-1.5-$ \\
$7.5-1-18^{* * *}$ \\
\end{tabular} & $\begin{array}{c}\text { Paired } \\
16-1.4-7-1 \\
-24\end{array}$ & $\begin{array}{c}\text { Closely paired } \\
8-1.15-6-1 \\
-20^{* * *}\end{array}$ \\
\hline $\begin{array}{c}\text { First dorsal } \\
\text { pore }\end{array}$ & (4/5) 5/6 & $4 / 5$ & $\begin{array}{c}4 / 5^{*} \\
(4 / 5) 5 / 6^{* *} \\
5 / 6^{* * *}\end{array}$ & (3/4) $4 / 5$ & $\begin{array}{c}\text { From } 4 / 5 \text {, usually } \\
19 / 20^{* *} \\
17 / 18 \text { to } 23 / 24^{* * *}\end{array}$ \\
\hline Spermathecae & $\begin{array}{c}10,11 \text {, pores } 9 / 10 \\
10 / 11 \text { near } d\end{array}$ & $\begin{array}{l}10,11, \text { pores } \\
9 / 10,10 / 11 c\end{array}$ & $\begin{array}{c}10,11 \text {, pores } 9 / 10 \\
10 / 11 \text { near } c\end{array}$ & $\begin{array}{c}\text { 10, 11, large, } \\
\text { iridescent, pores } \\
9 / 10,10 / 11 c d\end{array}$ & $\begin{array}{c}9,10 \text {, pores in } 9 / 10 \\
10 / 11\end{array}$ \\
\hline Clitellum & $(24) 25-30(31)$ & $\begin{array}{c}\text { Annular in }(1 / 2 \\
24) 25-1 / 2 \\
31(31)\end{array}$ & $\begin{array}{c}24-30^{*} \\
(23) 24-29(30)^{* *} \\
24-29^{* *}\end{array}$ & $22,23-29,30$ & $\begin{array}{c}26-33^{*} \\
(25,26) 27-32(33)^{* *} \\
25,26(27)- \\
(32) 33^{* * *} \\
\end{array}$ \\
\hline T. pubertatis & $1 / \mathrm{n} 26-28(1 / 229)$ & $25-30$ & $\begin{array}{c}24-30^{*} \\
24-29,30^{* *} \\
1 / 225-28^{* * *}\end{array}$ & $23-(27) 28,29$ & \begin{tabular}{|c|}
$29-32^{*}$ \\
$(1 / 227,28) 29-30$ \\
$(31,32)^{* *}$ \\
$1 / n 28-31,32^{* * *}$ \\
\end{tabular} \\
\hline Gld. Morren & $\begin{array}{l}\text { 10-12, diverticula } \\
\text { in } 10\end{array}$ & $\begin{array}{l}\text { 11- } 12 \text {, no } \\
\text { diverticula }\end{array}$ & $\begin{array}{c}10-13 \text { diverticula in } \\
10^{* *} \\
11-14, \text { no } \\
\text { diverticula }^{* * *} \\
\end{array}$ & $\begin{array}{c}10,11,12 \text { small } \\
\text { diverticula in } 10\end{array}$ & $\begin{array}{l}\text { Diverticula in } 10 \\
\qquad 10-13^{* * *}\end{array}$ \\
\hline $\begin{array}{l}\text { Nephridial } \\
\text { vesicle }\end{array}$ & S - shaped & $?$ & Curved, reclined ${ }^{* * *}$ & J - shaped & Inverted $\mathrm{J}^{* * *}$ \\
\hline Typhlosole & $\begin{array}{l}\text { Bifid initially, later } \\
\text { simple }\end{array}$ & $?$ & Simple & Simple, pleated & $\begin{array}{l}\text { Circular, } \\
\text { transversally } \\
\text { pleated*** }\end{array}$ \\
\hline $\begin{array}{l}\text { Seminal } \\
\text { vesicles }\end{array}$ & $9,10,11,12$ & $9,10,11,12$ & $\begin{array}{c}9,11,12^{*} \\
9,10,11,12^{* *} \\
9,11,12^{* * *} \\
\end{array}$ & $9,11,12$ & $\begin{array}{c}9,11,12^{*} \\
9,(10), 11,12^{* *} \\
9,11,12^{* * *}\end{array}$ \\
\hline Others & $\begin{array}{l}\text { White tissue on top } \\
\text { of the dorsal vessel. }\end{array}$ & & $\begin{array}{c}\text { *Rosa (1894) } \\
\text { ** Díaz Cosín et al. } \\
(1985) \\
\text { *** Qiu and Bouché } \\
\text { (1998b) }\end{array}$ & $\begin{array}{l}\text { White tissue on } \\
\text { top of the dorsal } \\
\text { vessel }\end{array}$ & $\begin{array}{c}\text { *Rosa }(1897) \\
* * \text { Bouché }(1972) \\
* * * \text { Omodeo and } \\
\text { Rota }(2004)\end{array}$ \\
\hline
\end{tabular}

a more posterior segment and presents four pairs of seminal vesicles. In addition, it was only found in Bashkiria (Bashkortostan, Russia) (data from Omodeo 1956). The differences of E. gerardo $i$ with the remaining species included within Eiseniona by Omodeo 
(1956) and Qiu and Bouché (1998a, d) are clear in terms of the beginning of clitellum in segments 22,23 and the tubercula pubertatis in segment 23. A comparison of some characters of the species living in the western part of the geographic range of Eiseniona is shown in Table 3, excluding the hemiandric E. paradoxa and E. gavarnica.

Genetic divergence between E. gerardoi and E. albolineata (COI, uncorrected distances) is $14.09 \%$, which is within the interval of uncertainty proposed by Chang and James (2011), but still near the 15\% that these authors consider as indicative for different species in earthworms. Nevertheless there are enough morphological characters that permit the separation of the two species.

\section{References}

Álvarez J (1970) Nuevas formas de oligoquetos terrícolas para la fauna de la Península Ibérica. Boletín de la Real Sociedad española de Historia Natural (Sección Biológica) 68: 17-24.

Barros F, Carracedo F, Díaz Cosín DJ (1992) Karyological and allozymic study of Allolobophora molleri and several related taxa. Soil Biology \& Biochemistry 24, 12: 1242-1255. doi: 10.1016/0038-0717(92)90100-C

"BioBio, Biodiversity Indicators for European Farming Systems, Indicators for Biodiversity in Organic and Low Input Farming Systems" http://www.biobio-indicator.org/index. php?l=1

Blakemore RJ (2008) An updated list of valid, invalid and synonymous names of Criodriloidea and Lumbricoidea (Annelida: Oligochaeta: Criodrilidae, Sparganophilidae, Ailoscolecida, Hor-mogastridae, Lumbricidae, Lutodrilidae). A Series of Searchable Texts on Earthworm Biodi-versity, Ecology and Systematics from Various Regions of the World - Supplemental. CD publication under ICZN (1999: Art. 8). http://www.annelida.net/earthworm/ [accessed July, 2013]

Blakemore RJ (2010) Unraveling some Kinki worms (Annelida: Oligochaeta: Megadrili: Megascolecidae) Part II. Opuscula Zoologica 42(2): 191-206.

Blakemore RJ (2012a) On Schmarda's lost worm and some newly found New Zealand species. Journal of Species Research 1(2): 105-132. doi: 10.12651/JSR.2012.1.2.105

Blakemore RJ (2012b) Cosmopolitan Earthworms - an Eco-Taxonomic Guide to the Peregrine Species of the World. Vth Edition. VermEcology, Yokohama, 900 pp + 300 figs.

Blakemore RJ (2013) Restoration of London type of first earthworm - Lumbricus terrestris Linnaeus, 1758 (Annelida: Oligochaeta: Lumbricidae), and setting aside of a 'neo-neotype'. Opuscula Zoologica Budapest 44(2): 211-212. http://opuscula.elte.hu/opuscula44_2.htm

Blakemore RJ, Grygier MJ (2011) Unraveling some Kinki worms (Annelida: Oligochaeta: Megadrili: Lumbricidae) Part III. Journal of Soil Organisms 83(2): 231-244.

Blakemore RJ, Kupriyanova EK (2010) Unraveling some Kinki worms (Annelida: Oligochaeta: Megadrili: Moniligastridae) Part I. Opuscula Zoologica 40: 3-18.

Blakemore RJ, Kupriyanova E, Grygier MJ (2010) Neotypification of Drawida hattamimizu Hatai, 1930 (Oligochaeta: Megadrili: Moniligastridae) and the first COI sequence from an earthworm type. ZooKeys 41: 1-29. doi: 10.3897/zookeys.41.374 
Bouché MB (1972) Lombriciens de France Écologie et Systématique. Institut National de la Recherche Agronomique. Annales de Zoologie Ecologie animale. Numéro hors-série. Paris, $671 \mathrm{pp}$.

Briones MJI, Moran P, Posada D (2009) Are the sexual, somatic and genetic characters enough to solve nomenclatural problems in lumbricid taxonomy? Soil Biology \& Biochemistry 41: 2257-2271. doi: 10.1016/j.soilbio.2009.07.008

Chang CH, James S (2011) A critique of earthworm molecular phylogenetics. Pedobiologia 54 (supplement S3-S9).

Chakrabarty P (2010) Genetypes: a concept to help integrate molecular phylogenetics and taxonomy. Zootaxa 2632: 67-68.

Csuzdi Cs (2012) Earthworm species, a searchable database. Opuscula Zoologica, Budapest, 43(1): 97-99.

Cognetti L (1904) Lombricidi dei Pirinei. Bolletino dei Musei di Zoología ed Anatomía comparata della R. Univesità di Torino 19, 476: 1-14.

Díaz Cosín DJ, Trigo D, Mato S (1989) Contribución al conocimiento de los lumbrícidos de la Península Ibérica. III. Eiseniona albolineata n. sp. Boletín de la Real Sociedad española de Historia Natural (Sección Biológica) 84, 3-4: 363-370.

Díaz Cosín DJ, Trigo D, Mascato R (1992) Earthworms of Iberian Peninsula. Species list and some biogeographical considerations. Soil Biology \& Biochemistry 24: 1351-1356. doi: 10.1016/0038-0717(92)90117-G

Dupont L, Lazrek F, Porco D, King RA, Rougerie R, Symondson WOC, Livet A, Richard B, Decaëns T, Butt KR, Mathieu J (2011) New insight into the genetic structure of the Allolobophora chlorotica aggregate in Europe using microsatellite and mitochondrial data. Pedobiologia 54: 217-224. doi: 10.1016/j.pedobi.2011.03.004

Easton EG (1983) A guide to the valid names of Lumbricidae (Oligochaeta). In: Satchell JE (Ed) Earthworm Ecology from Darwin to vermiculture. Chapman et Hall, London, 475485. doi: 10.1007/978-94-009-5965-1_41

Excoffier L, Laval G, Schneider S (2005) Arlequin ver. 3.0: An integrated software package for population genetics data analysis. Evolutionary Bioinformatics Online 1: 47-50.

Fernández R, Almodóvar A, Novo M, Gutiérrez M, Díaz Cosín DJ (2011) A vagrant clone in a peregrine species: phylogeography, high clonal diversity and geographical distribution in the earthworm Aporrectodea trapezoides (Dugès, 1828). Soil Biology \& Biochemistry 43, 10: 2085-2093. doi: 10.1016/j.soilbio.2011.06.007

Fernández R, Almodóvar A, Novo M, Simancas B, Díaz Cosín DJ (2012) Adding complexity to the complex: New insights into the phylogeny, diversification and origin of parthenogenesis in the Aporrectodea caliginosa species complex (Oligochaeta, Lumbricidae). Molecular Phylogenetics and Evolution 64: 368-379. doi: 10.1016/j.ympev.2012.04.011 James SW, Porco D, Decaëns T, Richard B, Rougerie R, Erseus C (2010) DNA Barcoding Reveals Cryptic Diversity in Lumbricus terrestris L., 1758 (Clitellata): Resurrection of L. herculeus (Savigny, 1826). PLoS ONE 5(12): e15629. doi: 10.1371/journal.pone.0015629

King RA, Tibble AL, Symondson WOC (2008) Opening a can of worms: unprecedented sympatric speciation within British lumbricid earthworms. Molecular Ecology 17: 4684-4698. doi: 10.1111/j.1365-294X.2008.03931.x 
Michaelsen W (1900) Oligochaeta. Das Tierreich 10. P. Friedlander and Sohn, Berlin, 575 pp. Mrsic N (1991) Monograph on earthworms (Lumbricidae) of the Balkans I, II. Slovenska akademija znanosti in umetnosti, Ljubljana 1881, 757 pp.

Novo M, Almodóvar A, Díaz Cosín DJ (2009) High genetic divergence of hormogastrid earthworms (Annelida, Oligochaeta) in the central Iberian Peninsula: evolutionary and demographic implications. Zoologica Scripta 38: 537-552. doi: 10.1111/j.14636409.2009.00389.x

Novo M, Almodóvar A, Fernández R, Trigo D, Díaz Cosín DJ (2010) Cryptic speciation of hormogastrid earthworms revealed by mitochondrial and nuclear data. Molecular Phylogenetics and Evolution 56: 507-512. doi: 10.1016/j.ympev.2010.04.010

Novo N, Almodóvar A, Fernández R, Giribet G, Díaz Cosín DJ (2011) Understanding the biogeography of a group of earthworms in the Mediterranean basin-The phylogenetic puzzle of Hormogastridae (Clitellata: Oligochaeta). Molecular Phylogenetics and Evolution 61: 125-135. doi: 10.1016/j.ympev.2011.05.018

Novo M, Fernández R, Fernández Marchán D, Gutiérrez M, Díaz Cosín DJ (2012) Compilation of morphological and molecular data, a necessity for taxonomy: The case of Hormogaster abbatissae sp. n. (Annelida, Clitellata, Hormogastridae). Zookeys 242: 1-16. doi: 10.3897/zookeys.242.3996

Omodeo P (1956) Contributo alla revisione dei Lumbricidae. Archivio Zoologico Italiano 1956, 41: 129-212.

Omodeo P, Rota E (2004) Taxonomic Remarks on the earthworms inhabiting the Western Alps. In: Moreno AG, Borges S (Eds) Advances in Earthworm Taxonomy. Editorial Complutense, Madrid, Spain, 220-259.

Qiu JP, Bouché MB (1998a) Révision des taxons supraspécifiques de Lumbricoidea. Documents Pédozoologiques et Intégrologiques 3: 179-216.

Qiu JP, Bouché MB (1998b) Contribution à la taxonomie des Avelonini trib. nov. (Oligochaeta: Lumbricidae). Avelona gen. nov., Koinodrilus gen.nov et Nicodrilus cuendeti sp.nov. Documents Pédozoologiques et Intégrologiques 4: 109-116

Qiu JP, Bouché MB (1998c) Contribution à la taxonomie des Dendrobaenini trib. Nov. (Oligochaeta: Lumbricidae). Iberoscolex gen. nov. et nouveaux taxons de Dendrobaena Eisen, 1874 et Satchellius Gates, 1975. Documents Pédozoologiques et Intégrologiques 4: 153-163.

Qiu JP, Bouché MB (1998d) Liste clase des taxons valides de lombriciens (Oligochaeta, Lumbricoidea), après l'étude des trois cinquièmes d'entre eux. Documents Pédozoologiques et Intégrologiques 4: 181-200.

Rodríguez T, Trigo D, Díaz Cosín DJ (1997) Biogeographical zonation of the western Iberian peninsula on the basis of the distribution of earthworm species. Journal of Biogeography 24: 893-901. doi: 10.1046/j.1365-2699.1997.00112.x

Rosa D (1894) Allolobophora ganglbaueri ed A. oliveirae nuove specie di lumbricidi europei. Bollettino dei Musei di Zoologia ed Anatomia comparata della R. Università di Torino 9, 170: $1-3$.

Rosa D (1897) Nuovi lombrichi dell'Europa orientale. Bollettino dei Musei di Zoologia ed Anatomia comparata della R. Università di Torino 12, 269: 1-5. 
Rota E (2013) Eiseniona. In: Fauna Europaea version 2.6.2. http://www.faunaeur.org, http:// www.faunaeur.org/full_results.php?id=178037 [accessed january 2014]

Sánchez EG, Jesús JB, Muñoz B, Parejo C (1998) Lombrices de tierra de Cáceres, Badajoz y Huelva. I. Géneros Allolobophora, Eisenia, Eiseniella y Lumbricus (Annelida, Oligochaeta). Boletín de la Real Sociedad española de Historia Natural (Sección Biológica) 91(3-4): 31-40.

Sánchez EG, Jesús JB, Muñoz B, Parejo C (1999) Lombrices de tierra de Cáceres, Badajoz y Huelva. II. Familias Acanthodrilidae (género Microscolex), Megascolecidae (género Amynthas), Ocnerodrilidae (género Eukerria) y otros Lumbricidae (géneros Dendrobaena, Octodrilus y Octolasion). Boletín de la Real Sociedad española de Historia Natural (Sección Biológica) 95(1-2): 57-62.

Zicsi A (1982) Verzeichnis der bis 1971 beschriebenen und revidierten Taxa der Familie Lumbricidae (Oligochaeta). Acta Zoologica Academiae Scientiarum Hungaricae 28: 421-454. 